\title{
Phytoprotection
}

\section{Intra- and interspecific interactions among Tribolium castaneum and Cryptolestes ferrugineus in stored wheat at different insect densities [Interactions intra et interspécifiques de Tribolium castaneum
et Cryptolestes ferrugineus à diverses densités dans le blé
entreposé]}

\author{
Raj B. Hulasare, Noel D.G. White, Digvir S. Jayas et Colin J. Demianyk
}

Volume 84, numéro 1, avril 2003

URI : https://id.erudit.org/iderudit/007441ar

DOI : https://doi.org/10.7202/007441ar

\section{Aller au sommaire du numéro}

Éditeur(s)

Société de protection des plantes du Québec (SPPQ)

ISSN

0031-9511 (imprimé)

1710-1603 (numérique)

Découvrir la revue

Citer cet article

Hulasare, R. B., White, N. D., Jayas, D. S. \& Demianyk, C. J. (2003). Intra- and interspecific interactions among Tribolium castaneum and Cryptolestes ferrugineus in stored wheat at different insect densities. Phytoprotection, 84(1), 19-26. https://doi.org/10.7202/007441ar

\section{Résumé de l'article}

Cryptolestes ferrugineus et Tribolium castaneum sont des ravageurs des grains entreposés responsables d'importantes pertes économiques au Canada. Ces insectes ont été élevés en laboratoire $\left(30^{\circ} \mathrm{C}\right.$ et $\left.70 \% \mathrm{HR}\right)$ séparément ou ensemble sur du blé roux vitreux de printemps à trois densités d'insectes, soit 1000,500 et 250 adultes par kilogramme de blé pour les espèces séparées, et au double de ces densités pour les espèces mélangées. Cette expérience a été menée avec du blé sec (12\% de contenu en humidité [CH] ou de teneur en eau) et humide ( $15 \%$ de $\mathrm{CH}$ ou de teneur en eau). Les adultes ont été échantillonnés aux 2 semaines sur une période de 10 semaines. Le blé tamisé a été incubé à $30^{\circ} \mathrm{C}$ et $70 \%$ HR durant 4 semaines afin d'observer le nombre d'adultes qui ont émergé des insectes immatures présents sous les téguments des germes de blé. Toutes les expériences ont été répétées quatre fois. La densité initiale des insectes, le contenu en humidité et la combinaison des espèces ont eu des impacts significatifs sur la population finale. Le nombre d'adultes des deux espèces a été plus élevé avec le blé à $15 \%$ de $\mathrm{CH}$. Avec le blé à $12 \%$ de $\mathrm{CH}$, le nombre de $T$. castaneum a été plus élevé que le nombre de $C$. ferrugineus lorsqu'ils ont été élevés séparément, alors que ce fut le contraire avec le grain à $15 \%$ de $\mathrm{CH}$. Les populations de Cryptolestes ferrugineus ont été

significativement plus élevées lorsque élevées avec le $T$. castaneum que lorsque élevées isolément sur le grain à $12 \% \mathrm{de} \mathrm{CH}$. Cette tendance a été inversée avec le grain à $15 \%$ de $\mathrm{CH}$. Pour les deux contenus en humidité des grains, le nombre de $T$. castaneum a été plus grand lorsque élevé seul par rapport à un élevage avec le $C$. ferrugineus. L'étude laisse supposer que les populations de $T$. castaneum sont inhibées par la présence de $C$. ferrugineus. Des densités d'insectes élevées accentuent souvent cet effet. 


\title{
Intra- and interspecific interactions among Tribolium castaneum and Cryptolestes ferrugineus in stored wheat at different insect densities
}

\author{
Raj B. Hulasare ${ }^{1}$, Noel D.G. White ${ }^{2}$, Digvir S. Jayas ${ }^{1}$, and \\ Colin J. Demianyk ${ }^{2}$
}

Received 2002-12-12; accepted 2003-06-03

\section{PHYTOPROTECTION 84 : 19-26}

Cryptolestes ferrugineus and Tribolium castaneum are important economical pests of stored grain in Canada. Insects were reared separately or together on hard red spring wheat at three insect densities representing 1000,500 , and 250 adults per kilogram of wheat for single species and twice that of single densities for mixed species, in the laboratory $\left(30^{\circ} \mathrm{C}, 70 \% \mathrm{RH}\right)$. The experiment was conducted on dry $(12 \%$ moisture content [MC], wet basis) and damp wheat (15\% MC, wet basis). Adults were sampled every 2 weeks over a 10 -week period. Sifted wheat was incubated at $30^{\circ} \mathrm{C}, 70 \%$ $\mathrm{RH}$ for 4 weeks to observe the number of adults emerging from immatures present under the seed coat of the wheat germ. All experiments were replicated four times. Initial insect densities, moisture content, and species combination had significant effects on the resulting adult population. Adult numbers for both species were higher on $15 \% \mathrm{MC}$ wheat. In $12 \% \mathrm{MC}$ wheat, $T$. castaneum numbers were higher than $C$. ferrugineus numbers when reared separately whereas this was reversed in 15\% MC grain. Cryptolestes ferrugineus populations were significantly higher when reared with $T$. castaneum than when reared as a single species on $12 \% \mathrm{MC}$ grain. The trend was reversed in $15 \% \mathrm{MC}$ grain. At both grain moistures, $T$. castaneum numbers were higher as an isolated species compared to when reared with C. ferrugineus. The study suggested that $T$. castaneum populations were inhibited in the presence of $C$. ferrugineus. High insect density often accentuated these effects.

[Interactions intra et interspécifiques de Tribolium castaneum et Cryptolestes ferrugineus à diverses densités dans le blé entreposé]

Cryptolestes ferrugineus et Tribolium castaneum sont des ravageurs des grains entreposés responsables d'importantes pertes économiques au Canada. Ces insectes ont été élevés en laboratoire $\left(30^{\circ} \mathrm{C}\right.$ et $\left.70 \% \mathrm{HR}\right)$ séparément ou ensemble sur du blé roux vitreux de printemps à trois densités d'insectes, soit 1000, 500 et 250 adultes par kilogramme de blé pour les espèces séparées, et au double de ces densités pour les espèces mélangées. Cette expérience a été menée avec du blé sec $(12 \%$ de contenu en humidité $[\mathrm{CH}]$ ou de teneur en eau) et humide (15\% de $\mathrm{CH}$ ou de teneur

1. Department of Biosystems Engineering, University of Manitoba, Winnipeg, MB, Canada R3T 5V6; email : digvir_jayas@umanitoba.ca

2. Cereal Research Centre, Agriculture and Agri-Food Canada, 195 Dafoe Road, Winnipeg, MB, Canada R3T 2M9 
en eau). Les adultes ont été échantillonnés aux 2 semaines sur une période de 10 semaines. Le blé tamisé a été incubé à $30^{\circ} \mathrm{C}$ et $70 \% \mathrm{HR}$ durant 4 semaines afin d'observer le nombre d'adultes qui ont émergé des insectes immatures présents sous les téguments des germes de blé. Toutes les expériences ont été répétées quatre fois. La densité initiale des insectes, le contenu en humidité et la combinaison des espèces ont eu des impacts significatifs sur la population finale. Le nombre $d^{\prime}$ adultes des deux espèces a été plus élevé avec le blé à $15 \%$ de $\mathrm{CH}$. Avec le blé à $12 \%$ de $\mathrm{CH}$, le nombre de $T$. castaneum a été plus élevé que le nombre de $C$. ferrugineus lorsqu'ils ont été élevés séparément, alors que ce fut le contraire avec le grain à $15 \%$ de $\mathrm{CH}$. Les populations de Cryptolestes ferrugineus ont été significativement plus élevées lorsque élevées avec le $T$. castaneum que lorsque élevées isolément sur le grain à $12 \%$ de $\mathrm{CH}$. Cette tendance a été inversée avec le grain à $15 \%$ de $\mathrm{CH}$. Pour les deux contenus en humidité des grains, le nombre de $T$. castaneum a été plus grand lorsque élevé seul par rapport à un élevage avec le $C$. ferrugineus. L'étude laisse supposer que les populations de $T$. castaneum sont inhibées par la présence de $C$. ferrugineus. Des densités d'insectes élevées accentuent souvent cet effet.

\section{INTRODUCTION}

Stored grain on farms in Western Canada is often infested by two major granivorous pests: the rusty grain beetle, Cryptolestes ferrugineus (Stephens) [Coleoptera: Laemophloeidae], and the red flour beetle, Tribolium castaneum (Herbst) [Coleoptera: Tenebrionidae] (Madrid et al. 1990). These two species are cosmopolitan in distribution but differ in food habits, tolerance for abiotic physical factors, and population characteristics. Cryptolestes ferrugineus is cold-hardy, tolerates low relative humidities down to $10 \%$ (Howe 1965), can survive to $-15^{\circ} \mathrm{C}$ for several wk after acclimatization (Fields 1992) and its population can increase 60 -fold in $4 \mathrm{wk}$ (Sinha and Watters 1985). Tribolium castaneum is cold-susceptible, has greater tolerance to low humidities as low as $1 \%$ (Howe 1965), thrives on broken kernels, dockage, and flour and populations can increase 70 -fold in 4 wk (Sinha and Watters 1985). The range of temperature in which stored-product insects can normally survive lies between $8-41^{\circ} \mathrm{C}$ (Sinha and Watters 1985), and most economically important insect pests of stored-products develop and reproduce over a narrower optimal range of temperature between $20-35^{\circ} \mathrm{C}$ (White 1995). Generally, development and multiplication are optimal near $30^{\circ} \mathrm{C}$ and $50-70 \%$ RH (Howe 1965). Cryptolestes ferrugineus successfully develops at $20-40^{\circ} \mathrm{C}$ and $40-95 \% \mathrm{RH}$ (optimum $32-35^{\circ} \mathrm{C}$ and $70-90 \% \mathrm{RH}$ ) and $T$. castaneum at the same temperatures but $10-95 \%$ RH (optimum $70-75 \%$ RH) (Sinha and Watters 1985).

Canadian grain is usually stored below $20^{\circ} \mathrm{C}$ except immediately after harvest when grain can be binned at temperatures of $30^{\circ} \mathrm{C}$ or more (Kawamoto et al. 1991). Wheat is stored at a straight grade of $14.5 \%$ moisture content (MC) or less (Canadian Grain Commission 2002) which has an equilibrium $\mathrm{RH}$ of $70 \%$ (Muir 1973). In years with wet harvest conditions, grain can be placed into storage at higher than straight grade MC which can promote mold growth. Grain can also be stored from several mo up to $2 \mathrm{yr}$ in large nonaerated grain bulks (Jayas et al. 1991) which remain warm in the bulk centre. These conditions are favorable for development of stored-product pests.

Numerous studies (Hagstrum and Throne 1989; Kabir 1966; Lefkovitch 1968; White and Sinha 1980) have been conducted in the laboratory on interactions among various species of storedproduct beetles. Kabir (1966) reported laboratory interactions among Sitophilus oryzae (L.), Rhyzopertha dominica (F.), and T. castaneum on sorghum and 
found that $R$. dominica and $S$. oryzae mutually inhibited development of each other whereas $T$. castaneum benefited from the presence of either or both species. Lefkovitch (1968) observed laboratory interactions among $S$. oryzae, Lasioderma serricone (F.), T. castaneum, and $C$. ferrugineus at $30^{\circ} \mathrm{C}$ and $60 \% \mathrm{RH}$. He reported that on both wheat and wheat-feed, $C$. ferrugineus inhibited $T$. castaneum and that $C$. ferrugineus would be the most likely to survive among all four species (Lefkovitch 1968).

The objective of this research was to study adult populations of $C$. ferrugineus and $T$. castaneum separately and together under insect densities of 250, 500 , and 1000 insects per $\mathrm{kg}$ in $12 \%$ and $15 \%$ MC wheat, respectively. These MC represent an equilibrium $\mathrm{RH}$ of $60 \%$ and $75 \%$, respectively (Muir 1973). The questions addressed were whether: 1) any one species had an inhibitory effect on the population of the other species when they are reared together compared to their numbers in isolation; 2) insect density had a significant effect on adult populations of the two species in isolation or in combination; 3 ) initial grain moisture had a significant effect on adult populations of the two species. Data from this experiment may be used to develop ecological models which could aid extension personnel or grain storage managers in predicting potential storage problems related to insect infestation.

\section{MATERIALS AND METHODS}

\section{Insects and Sex Ratio}

Cryptolestes ferrugineus were reared in laboratory cultures on whole wheat plus wheat germ (19:1, wt:wt) and $T$. castaneum were reared on wheat flour plus Brewer's yeast (19:1, wt:wt), at 30 $\pm 1{ }^{\circ} \mathrm{C}$ and $70 \pm 5 \% \mathrm{RH}$. The adults of both species used in the experiments were 2- to 3-wk-old. Sexing of T. castaneum was done by identifying the sex of pupae based on the pupal genital papillae in Tenebrionidae (Halstead 1963) and of $C$. ferrugineus as adults based on a mandibular projection on males (Rilett 1949). Three replicates each of 100 pupae of $T$. castaneum and adults of $C$. ferrugineus, were sexed in the laboratory. The mean sex ratio of 100 individuals was 51:49 for T. castaneum and 35:65 for $C$. ferrugineus (males to females). These values for sex ratio for the two species are similar to those reported by other researchers (Kawamoto et al. 1989; Rilett 1949; Smith 1966).

\section{Experimental Setup}

Certified hard red spring wheat, cultivar AC Barrie, with $5 \%$ dockage (finely ground wheat) by weight, and at two moisture contents of $12 \%$ and $15 \%$ wet basis (wb) was used as food for both insect species. Glass bottles of $224 \mathrm{~mL}$ capacity and $10 \mathrm{~cm}$ diam with perforated lids were used to store the grain with insects. Each glass bottle contained $150 \mathrm{~g}$ of wheat inclusive of $5 \%$ dockage. Adult insects of the two species were inserted singly or together at three densities. Hence a glass bottle with 150 g of wheat contained 37,75 , and 150 adults of each species, designated as low, medium, and high insect densities, respectively. For species reared together, each glass bottle contained 37,75 , and 150 adults of each species, for a total of 74, 150, and 300 insects at low, medium, and high insect densities, respectively. Adult counts were taken at $2,4,6,8$, and $10 \mathrm{wk}$. Four replicates were prepared for the three initial insect densities and species combinations (two single species and one in combination), and two moisture contents. Separate sets of bottles were prepared for each time interval. This was done to minimize the error due to repeated handling of the same grain at several time intervals of sampling. In all, 360 bottles were prepared with insects in isolation and combination and 72 bottles were sampled at each of $2,4,6,8$, and $10 \mathrm{wk}$. All bottles were kept in a temperature controlled chamber at $30^{\circ} \mathrm{C}$ and $70 \% \mathrm{RH}$. These standard nearoptimal conditions allowed for successful population growth (Sinha and Watters 1985) while preventing fungal contamination (Wicklow 1995).

At the various sampling intervals, the bottles were removed, the grain sieved on a \#10 screen (2-mm apertures), and adults carefully removed with an aspi- 
ration tube. With the adults removed, the remaining immatures and grain were returned to the bottles and incubated at $30^{\circ} \mathrm{C}$ and $70 \% \mathrm{RH}$ for 4 wk to determine the number of adults emerging. No other developmental stage of either species was counted. The number of live adults presented in the data are the adults removed by sieving at the end of each respective sampling interval $(2,4,6,8$, and $10 \mathrm{wk})$ plus the number of adults emerging from immatures after 4 wk of incubation.

\section{Statistical analysis}

To analyze the effect of various variables, the numbers of adults were cuberoot transformed (Steel and Torrie 1960) and analyzed by ANOVA (Proc GLM) (SAS 1995). Insect number was the dependent variable, and insect density, wheat moisture content, and species (separate or combined) were independent variables.

\section{RESULTS AND DISCUSSION}

Overall, moisture content and initial insect density had significant effects ( $F$ $=13.65)$ on the population of both $T$. castaneum and $C$. ferrugineus regardless of being reared separately or together. Adult populations of both species, irrespective of rearing method, were higher in $15 \% \mathrm{MC}$ wheat than in $12 \% \mathrm{MC}$ wheat (Tables 1 and 2). This was expected as humid conditions in damp wheat (above $14.5 \% \mathrm{MC}$ ) are more favourable for multiplication of insects than dry wheat (Howe 1965).

\section{Intraspecific interactions}

The singly raised populations of $C$. ferrugineus and $T$. castaneum were significantly affected by moisture content $(F=9104.46)$ and initial insect density $(F=104.66)$ over the span of the experiment. Again, the numbers were lower in $12 \% \mathrm{MC}$ grain compared to $15 \% \mathrm{MC}$ grain for both species.

Table 1. Mean \pm SE number of adult Cryptolestes fernugineus reared alone and with Tribolium castaneum from three initial insect densities in $150 \mathrm{~g}$ of $\mathbf{1 2 \%}$ (dry) and $15 \%$ (damp) moisture content (MC) wheat at $30^{\circ} \mathrm{C}$ and $70 \%$ relative humidity for all sample dates $(2,4$, 6, 8, and 10 weeks)

\begin{tabular}{|c|c|c|c|c|}
\hline \multirow{2}{*}{$\begin{array}{l}\text { Initial density } \\
\text { (no. adults of } \\
\text { each species } / 150 \mathrm{~g} \text { ) }\end{array}$} & \multicolumn{2}{|c|}{ Reared alone } & \multicolumn{2}{|c|}{ Reared with $T$. castaneum } \\
\hline & $12 \% \mathrm{MC}$ & $15 \% \mathrm{MC}$ & $12 \% \mathrm{MC}$ & $15 \% \mathrm{MC}$ \\
\hline Low (37) & $49 \pm 5$ & $927 \pm 46$ & $125 \pm 22$ & $688 \pm 35$ \\
\hline Medium (75) & $55 \pm 5$ & $1049 \pm 46$ & $88 \pm 6$ & $760 \pm 56$ \\
\hline High (150) & $91 \pm 10$ & $1096 \pm 53$ & $133 \pm 6$ & $882 \pm 25$ \\
\hline
\end{tabular}

$n=4$ replicates.

Table 2. Mean \pm SE number of adult Tribolium castaneum reared alone and with Cryptolestes ferrugineus from three initial insect densities in $150 \mathrm{~g}$ of $12 \%$ (dry) and $15 \%$ (damp) moisture content (MC) wheat at $30^{\circ} \mathrm{C}$ and $70 \%$ relative humidity for all sample dates $(2,4,6,8$, and 10 weeks)

\begin{tabular}{lccccc}
\hline $\begin{array}{l}\text { Initial density } \\
\text { (no. adults of }\end{array}$ & \multicolumn{2}{c}{ Reared alone } & & \multicolumn{2}{c}{ Reared with C. ferrugineus } \\
\cline { 2 - 3 } \cline { 5 - 6 } each species/150 g) & $12 \% \mathrm{MC}$ & $15 \% \mathrm{MC}$ & & $12 \% \mathrm{MC}$ & $15 \% \mathrm{MC}$ \\
\hline Low (37) & $159 \pm 11$ & $397 \pm 29$ & & $105 \pm 15$ & $127 \pm 14$ \\
Medium (75) & $215 \pm 20$ & $483 \pm 26$ & & $116 \pm 8$ & $123 \pm 11$ \\
High (150) & $289 \pm 18$ & $575 \pm 28$ & & $179 \pm 8$ & $196 \pm 16$ \\
\hline
\end{tabular}

$n=4$ replicates. 
Figures 1 to 4 represent the mean adult population (adult count at each sampling interval plus the adults emerging from immatures after 4 wk of incubation); standard errors (SE) are in parenthesis, for the two species under $12 \%$ and $15 \%$ MC grain rearing conditions. For $C$. ferrugineus alone, mean populations at all the three insect densities were significantly higher in $15 \%$ than $12 \% \mathrm{MC}$ grain (Figs. 1 and 2). A similar trend was observed for $T$. castaneum (Figs. 3 and 4). For single species in $12 \%$ MC grain, however, mean populations were higher for T. castaneum than $C$. ferrugineus over all insect densities (Tables 1 and 2). This observation confirms the slightly higher rate of increase of $T$. castaneum compared to $C$. ferrugineus (Sinha and Watters 1985) and reflects a greater ability of $T$. castaneum to survive over a wider range of relative humidity (White 1995). Tribolium castaneum is one of the most cosmopolitan pests of stored cereals and other foods (Sinha and Watters 1985).
For single species in 15\% MC grain, overall mean numbers of $C$. ferrugineus at low, medium, and high densities were 2.3-, 2.2-, and 1.9-fold higher, respectively, than $T$. castaneum numbers (Tables 1 and 2). Sinha (1975) observed $C$. ferrugineus adult populations to be 1.2fold higher than T. castaneum in stored wheat with a 5\% dockage level after 12 wk. The lower population of $T$. castaneum in $15 \%$ MC grain can be attributed to a crowding effect which reduces fecundity (Rich 1956; Sonleitner 1961) and to a high incidence of cannibalism in confined laboratory populations of Tribolium (Park 1934). Under extreme circumstances, eggs, pupae, and callow adults have suffered mortality greater than $90 \%$ due to predation by larvae and mature adults of their own species (Rich 1956; Sonleitner 1961).

\section{Interspecific interactions}

In $12 \%$ MC grain, $C$. ferrugineus adult numbers were significantly higher when reared in combination with $T$. castaneum than when reared in isolation, at all

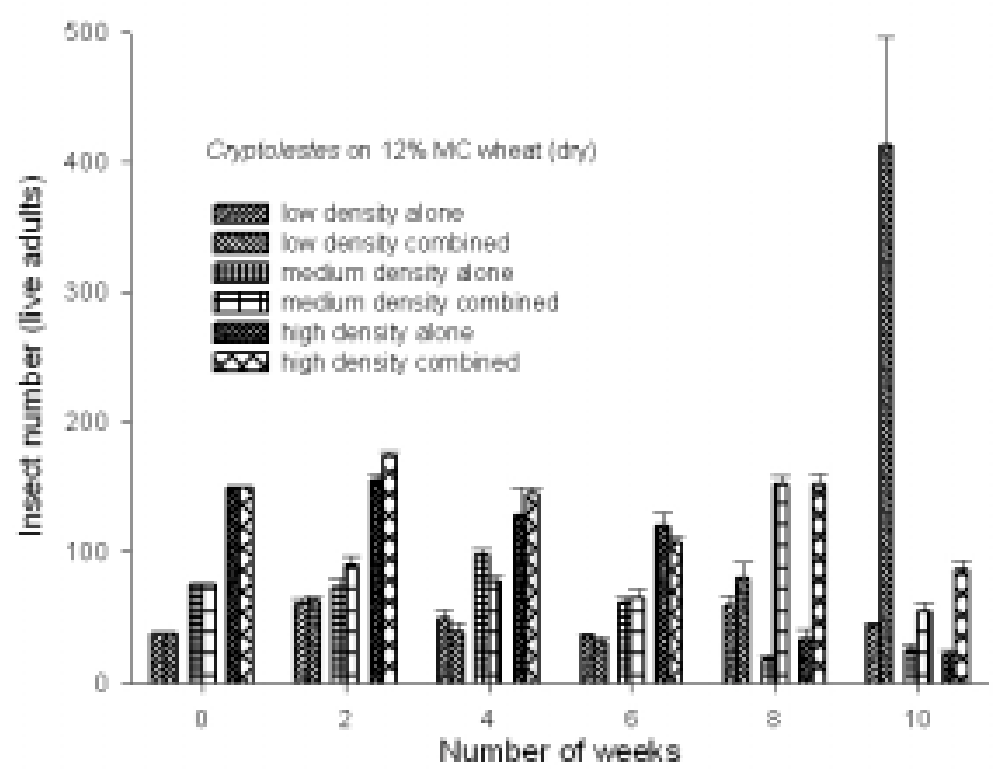

FIGURE 1. Mean \pm SE number of adult Cryptolestes fernugineus at initial low, medium, and high densities, reared alone or in combination with Tribolium castaneum in $150 \mathrm{~g}$ of $12 \%$ MC (dry) wheat. (Numbers are represented by the adult observed at the sampling intenval plus the adults eclosing from pupae after incubation of 4 weeks). 


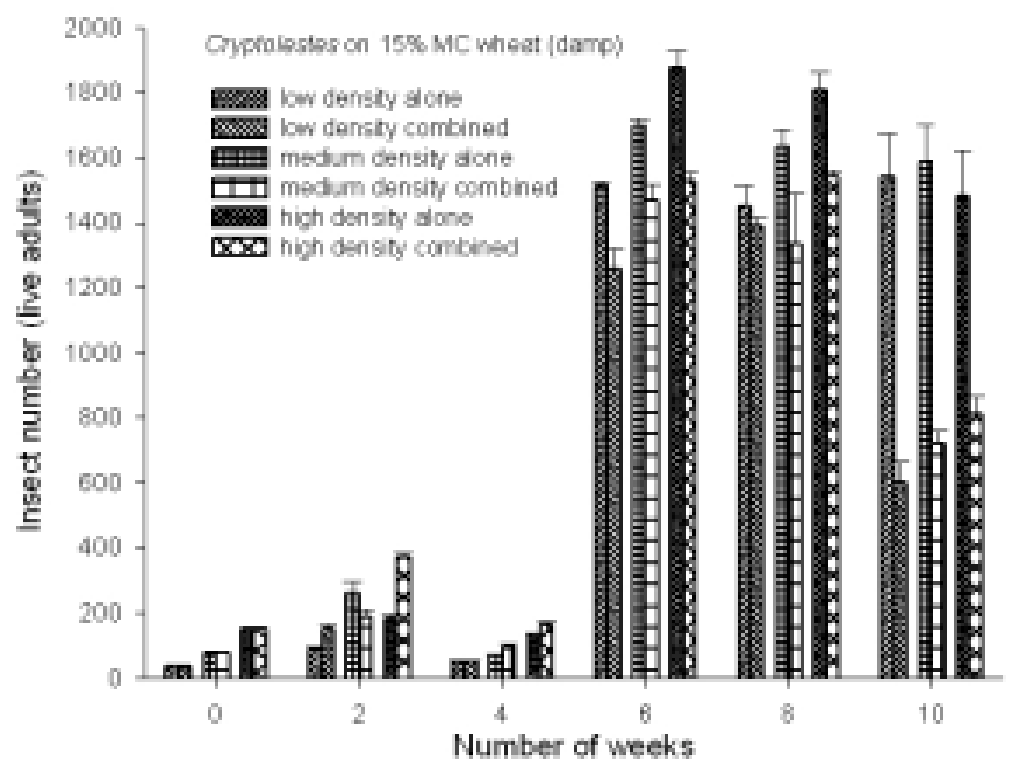

FIGURE 2. Mean \pm SE number of adult Cryptolestes ferrugineus at initial low, medium, and high densities reared alone or in combination with Tribolium castaneum in $150 \mathrm{~g}$ of $15 \%$ MC (damp) wheat. (Numbers are represented by the adult observed at the sampling interval plus the adults eclosing from pupae after incubation of 4 weeks).

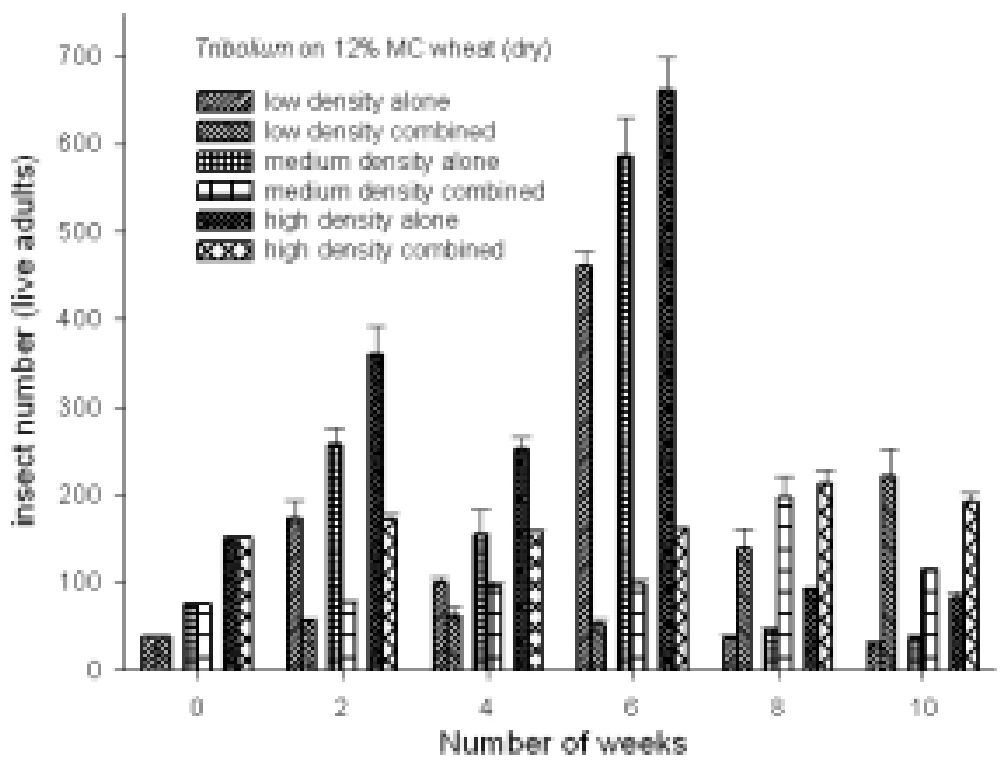

FIGURE 3. Mean \pm SE number of adult Tribolium castaneum at initial low, medium, and high densities, reared alone or in combination with Cryptolestes ferrugineus in $150 \mathrm{~g}$ of $12 \%$ MC (dry) wheat. (Numbers are represented by the adult observed at the sampling interval plus the adult eclosing from pupae after incubation of 4 weeks). 


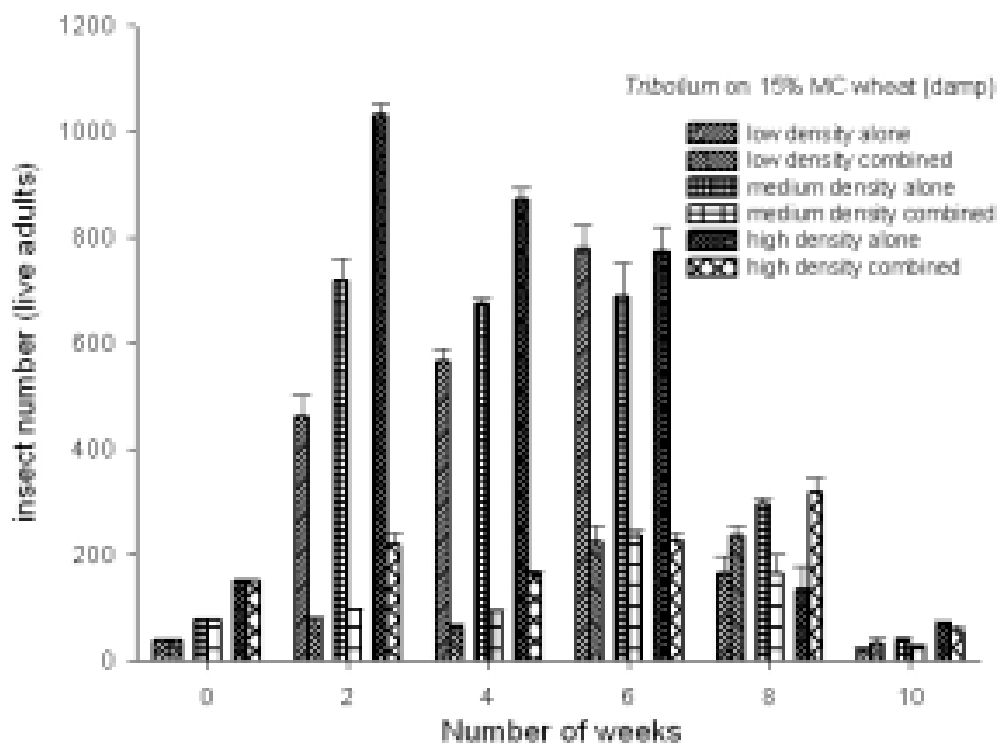

FIGURE 4. Mean \pm SE number of adult Tribolium castaneum at initial low, medium, and high densities reared alone or in combination with Cryptolestes ferrugineus in $150 \mathrm{~g}$ of $15 \%$ MC (damp) wheat. (Numbers are represented by the adult observed at the sampling interval plus the adults eclosing from pupae after incubation of 4 weeks).

three densities (Fig. 1; Tables 1 and 2). However, this trend was reversed in $15 \%$ MC grain, where $C$. ferrugineus populations were significantly higher in isolation than when reared with $T$. castaneum (Fig. 2; Tables 1 and 2). It is possible that in dry grain, C. ferrugineus $1^{\text {st }}$ instar larvae were unable to penetrate the wheat germ because of their small size and the intact kernels. Grain damaged by $T$. castaneum feeding was easier for $C$. ferrugineus adults to feed on and for larvae to enter. White (1979), in a preliminary study, also observed that the population of $C$. ferrugineus was higher than $T$. castaneum in wheat at the end of 5,10 , and $15 \mathrm{wk}$ when reared together using an initial 25 adults of each species at $14.5 \%$ MC.

Suresh et al. (2001) observed that adults of $T$. castaneum caused more mortality of the immatures of both species than $C$. ferrugineus adults. They also observed that $T$. castaneum larvae caused higher mortality to their own species than to $C$. ferrugineus. Our results are consistent with previous observations, that $C$. ferrugineus has an inhibitory effect on $T$. castaneum populations. At the experimental densities tested, and under closed conditions where insects could not migrate from crowding pressure, cannibalism may have had a severe impact on the populations observed. In most Canadian conditions, where migration is possible, the effects may be tempered as insect densities are less, except for active "hot-spots." The density of Cryptolestes spp. found in wheat sampled from farms in northern US states during the summer and fall of 1980 was 45 insects per $\mathrm{kg}$ (Storey et al. 1983). Populations of $T$. castaneum would be expected to decline slowly because of cannibalism and predation by $C$. ferrugineus adults on the eggs and larvae of $T$. castaneum, while C. ferrugineus immatures were largely protected from predation by developing under the seed coat at the wheat germ (Suresh et al. 2001). In this study, T. castaneum populations remained static, showing little if any increase when combined with $C$. ferrugineus. 


\section{ACKNOWLEDGMENT}

This work was supported in part by an operating grant to D. S. Jayas from the Natural Sciences and Engineering Research Council of Canada.

\section{REFERENCES}

Canadian Grain Commission. 2002. Official grain grading guide. $2002 \mathrm{Ed}$. Canadian Grain Commission, Winnipeg, MB. 509 pp.

Fields, P.G. 1992. The control of storedproduct insects and mites with extreme temperatures. J. Stored Prod. Res. 28 : 89-118.

Hagstrum, D.W., and J .E. Throne. 1989. Predictability of stored-wheat insect population trends from life history traits. Environ. Entomol. 18 : 660-664.

Halstead, D.G.H. 1963. External sex differences in stored-products Coleoptera. Bull. Entomol. Res. 54 : 119-134.

Howe, R.W. 1965. A summary of estimates of optimal and minimal conditions for population increase of some stored products insects. J. Stored Prod. Res. 1 : 177184.

J ayas, D.S., B. Khangura, and N.D.G. White. 1991. Controlled atmosphere storage of grains. Postharvest News and Info. 2 : 423-427.

Kabir, S.M.H. 1966. Interactions in stored grain of populations of Sitophilus zeamais. Unpublished Ph.D. Dissertation. Texas $A$ and $M$ University, College Station, TX. $102 \mathrm{pp}$.

Kawamoto, H., R.N. Sinha, and W.E. Muir. 1989. Effect of temperature on adult survival and potential fecundity of the rusty grain beetle, Cryptolestes ferrugineus. Appl. Entomol. Zool. 24 : 418-423.

Kawamoto, H., R.N. Sinha, W.E. Muir, and S.E. Woods. 1991. Simulation model of Acarus siro (Acari: Acaridae) in stored wheat. Environ. Entomol. 20 : 1381-1386.

Lefkovitch, L.P. 1968. Interactions between four species of beetles in wheat and wheatfeed. J. Stored Prod. Res. 4 : 1-8.

Madrid, F.J ., N.D.G. White, and S.R. Loschiavo. 1990. Insects in stored cereals, and their association with farming practices in southern Manitoba. Can. Entomol. 122 : 515-523.

Muir, W.E. 1973. Temperature and moisture in grain storages. Pages $49-70$ in R.N. Sinha and W.E. Muir (eds.), Grain storage: Part of a system. The AVI Publ. Company, Westport, CT
Park, T. 1934. Observations on the general biology of the flour beetle Tribolium confusum. Q. Rev. Biol. $9: 36-54$.

Rich, E.R. 1956. Egg cannibalism and fecundity in Tribolium. Ecology 37 : 109-120.

Rilett, R.O. 1949. The biology of Laemophloeus ferrugineus (Steph.). Can. J. Res. Sec. D Zool. Sci. 27 : 112-148.

SAS. 1995. SAS user's guide: statistics. SAS Institute, Raleigh, NC. 956 pp.

Sinha, R.N. 1975. Effect of dockage in the infestation of wheat by some storedproduct insects. J. Econ. Entomol. 68 : 699-703.

Sinha, R.N., and F.L. Watters. 1985. Insect pests of flour mills, grain elevators, and feed mills and their control. Agriculture Canada Publication 1776E, Canadian Government Publication Centre, Ottawa, Canada. 290 pp.

Smith, L.B. 1966. Effect of crowding on oviposition, development and mortality of Cryptolestes ferrugineus (Stephens) (Coleoptera: Cucujidae). J. Stored Prod. Res. 2 : 91- 104.

Sonleitner, FJ . 1961. Factors affecting egg cannibalism and fecundity in populations of adult Tribolium castaneum Herbst. Physiol. Zool. 34 : 233-255.

Steel, R.G.D., and J .H. Tomie. 1960. Principles and procedures of statistics. McGraw-Hill Book Company, NY. 481 $\mathrm{pp}$.

Storey, C.L., D.B. Sauer, and D. Walker. 1983. Insect populations in wheat, corn, and oats stored on the farm. J. Econ. Entomol. 76 : 1323-1330.

Suresh S., N.D.G. White, D.S. J ayas, and R.B. Hulasare. 2001. Mortality caused by interactions between the red flour beetle, Tribolium castaneum and the rusty grain beetle, Cryptolestes ferrugineus. Proc. Entomol. Soc. Manitoba 57 : 11-18.

White, N.D.G. 1979. Interrelations in storedwheat ecosystems infested with multiple species of insects: a descriptive and multivariate analysis. Ph.D. dissertation, University of Manitoba, Winnipeg, MB. $181 \mathrm{pp}$.

White, N.D.G. 1995. Insects, mites, and insecticides in stored-grain ecosystems. Pages 123-167 in D.S. Jayas, N.D.G. White and W.E. Muir (eds.), Stored-grain ecosystems. Marcel Dekker inc, NY.

White, N.D.G., and R.N. Sinha. 1980. Changes in stored-wheat ecosystems infested with two combinations of insect species. Can. J. Zool. 58 : 1524-1534.

Wicklow, D.T. 1995. The mycology of stored grain: an ecological perspective. Pages 197-249 in D.S. Jayas, N.D.G. White and W.E.Muir (eds.), Stored-grain ecosystems. Marcel Dekker inc, NY. 